\title{
PEMBELAJARAN BAHASA INDONESIA DENGAN TEKNIK PERMAINAN KELOMPOK SISWA KELAS V DI SDN 110 LAGOARI DI KABUPATEN WAJO.
}

\author{
Surianto ${ }^{1}$,Andi Sukri Syamsuri ${ }^{2}$, Muhammad Akhir ${ }^{3 *}$ \\ 1,2,3Magister Pendidikan Dasar, Universitas Muhammadiyah Makassar, Indonesia \\ * Corresponding Author. E-mail: ${ }^{1}$ suriantolagoari@gmail.com
}

Receive: $12 / 01 / 2020$

Accepted:18/02/2020

Published: 03/03/2020

\begin{abstract}
Abstrak Secara umum rata-rata anak memiliki kemampuan berkomunikasi yang baik. Namun bila diperhatikan secara khusus atau secara individual kemampuan secara individu berbedabeda. Ada beberapa anak yang tergolong kesulitan dalam berkomunikasi dengan teman. Kesulitan-kesulitan tersebut membuat komunikasi antar teman menjadi tidak efektif. Apabila hal tersebut terus dibiarkan akan menghambat proses perkembangan sosial anak. Terhambatnya kemampuan berkomunikasi siswa juga dapat menghambat prestasi belajar siswa.Tujuan penelitian ini untuk menggambarkan pelaksanaan teknik permainan kelompok, mengetahui bagaimana tingkat kemampuan berkomunikasi siswa dan mengetahui pengaruh pelaksanaan teknik permainan kelompok dalam pembelajaran bahasa Indonesia terhadap kemampuan berkomunikasi siswa di SDN 110 Lagoari Kecamatan Takkalalla Kabupaten Wajo. Jenis penelitian ini adalah true experimen (eksperimen murni) pengujian variabel bebas dan terikat dilakukan terhadap sampel kelompok eksperimen dan kelompok kontrol. Desain eksperimen yang akan digunakan adalah Desain Randomized Pretest-Posttest Control Group Design. Teknik pengumpulan data melalui observasi untuk menilai kegiatan atau pengamatan terhadap perlakuan yang dilakukan guru di kelas eksperimen, angket untuk memperoleh informasi mengenai kemampuan berkomunikasi siswa dalam pembelajaran bahasa Indonesia dengan pelaksanaan teknik permainan kelompok, dan dokumentasi. Teknik analisis datanya analisis deskriftif dan analisis inferensial yang meliputi uji normalitas, uji homogenitas, dan uji hipotesis dengan uji $T$ Test. Hasil penelitian menunjukkan pelaksanaan teknik permainan kelompokdi kelas eksperimenterlaksana dengan baik berdasarkan sintaks pembelajaran. Tingkat kemampuan berkomunikasi siswa meningkat setelah diberikan perlakuan teknik permainan kelompok hasil pretes pada kelas eksperimen dari kategori cukup menjadi tinggi setelah postes itu berarti kemampuan berkomunikasi siswa meningkat setelah perlakuan teknik permainan kelompok. Peningkatan kemampuan berkomunikasi siswa dari sebelum dan setelah perlakuan teknik permainan kelompok berindikasi bahwa pelaksanaan teknik permainan kelompok berpengaruh signifikan terhadap kemampuan berkomunikasi siswa di sekolah dasar.
\end{abstract}

\section{Kata kunci : pembelajaran bahasa indonesi dengan teknik permainan kelompok,}

Abstract General good communicate ability have mean child In. But if attention paid when peculiarly of other each different individually ability individually. There of some pertained of child is friend with communicating in difficulty. Difficultys note becoming friend effective between communications make The. If the social child of growth process pursue will let be 
to continue mentioned. group of game technique of execution depict to students. Research this learn achievement pursue can also student communicate ability of The student communicate ability to Indonesian study in group of game technique of execution of influence know and student communicate storey level ability how knowing in SDN 110 Lagoari District Of Takkalalla Sub-Province Wajo.

this Research type is experimen true pure experiment examination of free variable and tied to be done/conducted to experiment group sampel and control group. Experiment Desain to be used by Desain Randomized Pretest-Posttest Control Group Design. Technique data collecting through observation to assess perception or activity to treatment which is to learn in experiment class, enquette to obtain, get information concerning ability communicate student in study of Indonesian with execution of technique game of group, and documentation. Technique analyse its data of analysis of deskriftif analysis and of inferensial covering test of normalitas, homogeneity test, and hypothesis test with test of T Test. Result of research show execution of technique game of experiment class executed better pursuant to study sintaks. Mount ability communicate student mount after given by treatment of technique game of group result of pretes at experiment class of category enough become high after that postes mean ability communicate student mount after treatment of technique game of group. Make-Up of ability communicate student from before and after treatment of technique game of group have indication to that execution of technique game of group have an effect on signifikan to ability communicate student in elementary school.

Keyword : study of language of indonesi with technique game of group

\section{PENDAHULUAN}

Pembelajaran bahasa Indonesia secara fungsional adalah pembelajaran yang lebih menekankan siswa belajar berbahasa dalam kaitannya dengan fungsi bahasa sebagai alat untuk berkomunikasi (Munira:2015). Pembelajaran bahasa Indonesia pada hakikatnya adalah membelajarkan peserta didik tentang keterampilan berbahasa Indonesia yang baik dan benar sesuai tujuan dan fungsinya.

Menurut Atmazaki (2013) mata pelajaran Bahasa Indonesia bertujuan agar peserta didik memiliki kemampuan berkomunikasi secara efektif dan efisien sesuai dengan etika yang berlaku, baik lisan ataupun tulisan, menghargai dan bangga menggunakan Bahasa Indonesia sebagai Bahasa Persatuan dan Bahasa Negara, memahami Bahasa Indonesia dan menggunakannya dengan tetap kreatif untuk berbagai tujuan-tujuan, menggunakan Bahasa Indonesia untuk meningkatkan kemampuan intelektual serta kematangan emosional dan sosial, menikmati dan memanfaatkan karya sastra untuk memperluas wawasan, budi pekerti, serta meningkatkan pengetahuan dan kemampuan berbahasa, dan menghargai dan membanggakan sastra Indonesia sebagai khazanah budaya dan intelektual Indonesia.

Bahasa Indonesia memegang
peranan penting dalam kehidupan manusia. Hal ini haruslah disadari benar, terutama oleh guru mata pelajaran bahasa dan sastra Indonesia pada khususnya dan guru bidang studi lain pada umumnya. Dalam menjalankan tugasnya sehari-hari, guru mata pelajaran bahasa harus memahami bahwa tujuan akhir pembelajaran bahasa adalah agar siswa dapat mempergunakan bahasa sebagai alat berkomunikasi, dan agar siswa terampil 
berbahasa, yakni terampil menyimak, berbicara, membaca, dan menulis.

Manusia adalah makhluk sosial yang dalam kehidupan sehari-hari senantiasa memerlukan orang lain. Menurut Tarrigan (1981:11) bahwa "komunikasi adalah serangkaian perbuatan Komunikasi atau speech acts yang dipergunakan secara sistematis untuk menyelesaikan atau mencapai maksudmaksud tertentu". Komunikasi adalah suatu hal yang penting dan sangat berharga. Keberhasilan seseorang dalam mencapai tujuan hidupnya sangat dipengaruhi oleh komunikasi. Hal ini karena dengan memiliki kemampuan komunikasi yang baik dan lancar akan mampu menghadapi apapun yang menjadi tujuan hidupnya dan berharap mendapat keberhasilan. Selain itu, ada sejumlah kebutuhan dalam diri manusia yang hanya dapat dipuaskan lewat berkomunikasi sesama.

Menurut pendapat Faturrohman (2007:41) bahwa "siswa memerlukan sesuatu yang memungkinkan dia berkomunikasi secara baik dengan guru, teman, maupun dengan lingkungannya". Siswa yang mengalami kesulitan berkomunikasi antar teman akan mengalami kesulitan untuk dapat menyesuaikan diri dengan temannya dan lingkungannya. Apabila kemampuan komunikasi dengan temannya terhambat itu dapat menyebabkan terhambatnya pemenuhan tugas perkembangannya dan mengganggu perkembangannya yang tentu saja akan menyebabkan tidak terpenuhinya tugas perkembangan selanjutnya. Terhambatnya kemampuan berkomunikasi juga dapat menghambat prestasi belajar siswa, siswa yang kesulitan dalam berkomunikasi dan tidak mampu bersosialisasi dan menyesuaikan diri dengan temannya.

Berdasarkan fenomena dilapangan hasil dari observasi dan wawancara dengan guru kelas V SD Negeri 110 Lagoari Kecamatan Takkalalla Kabupaten Wajo diperoleh informasi bahwa ada beberapa anak yang kesulitan dalam berkomunikasi. Dilihat secara umum rata-rata anak memiliki kemampuan berkomunikasi yang baik. Namun bila diperhatikan secara khusus atau secara individual kemampuan secara individu berbeda-beda. Ada beberapa anak yang tergolong kesulitan dalam berkomunikasi dengan teman. Kesulitan-kesulitan tersebut membuat komunikasi antar teman menjadi tidak efektif. Tidak efektifnya komunikasi terjadi karena siswa belum memenuhi faktorfaktor yang mempengaruhi komunikasi antar teman diantaranya adalah keterbukaan, empati, mendorong/dukungan, perasaan positif dan kesamaan.

Dalam Kurikulum Berbasis Kompetensi disebutkan adanya empat keterampilan berbahasa, yaitu mendengarkan atau menyimak, berbicara, membaca, dan menulis. Dalam pelaksanaan pembelajaran keempat keterampilan berbahasa tersebut seharusnya mendapatkan porsi yang seimbang dan dilaksanakan secara terpadu. Aspek-aspek itu disusun secara integratif ke dalam satu unit yang berurutan dari aspek yang pertama sampai dengan yang keempat. Keempat aspek tersebut merupakan satu kesatuan yang saling mempengaruhi satu dengan yang lain. Oleh karena itu, dalam pelaksanaan pembelajaran bahasa dan sastra Indonesia keempat aspek tersebut perlu diintegrasikan, dengan harapan siswa mampu menguasai materi secara menyeluruh. Untuk mengajarkan keterampilan berbahasa Indonesia, penyajian uraian atau penjelasan saja belum cukup. Latihan mengerjakan soal untuk melatihkan butir-butir tata bahasa

Permainan adalah suatu media yang mengasyikan dan memuaskan bagi 
anak untuk mempelajari sesuatu, dengan permainan anak belajar suatu hal tanpa disadari namun selalu diingat dan disimpan dalam memorinya karena sifatnya menyenangkan dan membantu anak mencapai perkembangan yang utuh, baik fisik, intelektual, sosial, moral, dan emosional. Permainan membuat anak tidak akan merasa bosan dan selalu antusias untuk mempelajari suatu hal yang belum ia ketahui. Permainan yang dirancang sedemikian rupa namun harus tetap dalam koridor kedisiplinan dan dapat merangsang anak dalam perkembangannya. Kegiatan bermain dalam kelompok membuat anak dapat belajar banyak hal yang didalamnya termasuk belajar berkomunikasi. Anak belajar berkomunikasi sehingga kemampuan komunikasi antar teman dapat meningkat. Banyak permainan yang dapat dilakukan untuk dapat meningkatkan kemampuan berkomunikasi siswa, dan dengan bermain tanpa sadar anak belajar untuk dapat mengembangkan kemampuan berkomunikasinya sehingga kemampuan berkomunikasi siswa yang dimilikinya dapat meningkat. Proses belajar tersebut tidak disadari anak dan juga tidak akan merasa terbebani karena dengan bermain anak merasa senang dan asyik. Apalagi objek yang akan peneliti teliti adalah siswa sekolah dasar yang masih senang bermain.

Menurut Undang-Undang Republik Indonesia No 20 tahun 2003 dipaparkan bahwa pendidikan merupakan usaha sadar dan terencana untuk mewujudkan suasana belajar dan proses pembelajaran agar peserta didik secara aktif mengembangkan potensi dirinya untuk memiliki kekuatan spiritual keagamaan, pengendalian diri, kepribadian, kecerdasan, akhlak mulia, serta keterampilan yang diperlukan dirinya, masyarakat, bangsa dan negara. 2

Dari fenomena tersebut peneliti akan meneliti dengan judul "Pembelajaran Bahasa Indonesia dengan Teknik Permainan Kelompok Siswa Sekolah Dasar
110 Lagoari Kecamatan Takkalalla Kabupaten Wajo".

\section{METODE}

Jenis penelitian ini adalah quasi experimen (eksperimen semu). Eksperimen ini disebut kuasi, karena bukan merupakan eksperimen murni tetapi seperti murni, seolah-olah murni. Eksperimen ini biasa juga disebut eksperimen semu. Karena berbagai hal, terutama berkenaan dengan pengontrolan variabel, kemungkinan sukar sekali dapat digunakan eksperimen murni. Eksperimen kuasi bisa digunakan minimal kalau dapat mengontrol satu variabel saja meskipun dalam bentuk matching, atau memasangkan/menjodohkan karakteristik, kalau bisa random lebih baik. Pengambilan sampel secara acak, berdasarkan karakteristik budaya, lingkungan, profesi orang tua yang sama di SD Negeri 110 Lagoari Kecamatan Takkalalla Kabupaten Wajo.

Lokasi penelitian ini berada di SD Negeri 110 Lagoari Kecamatan Takkalalla Kabupaten Wajo.

\section{Angket (kuesioner)}

Angket ini diberikan kepada siswa untuk memperoleh informasi mengenai kemampuan berkomunikasi siswa. Angket dibuat dengan model Likert yang mempunyai lima kemungkinan jawaban yang berjumlah genap ini dimaksud untuk menghindari kecenderungan responden bersikap ragu-ragu dan tidak mempunyai jawaban yang jelas.

Instrumen angket yang akan digunakan dalam penelitian tersebut diujikan pada sekolah yang bukan tempat penelitian tetapi memiliki karakter yang sama dengan sekolah tempat melakukan penelitian. Uji instrumenyang dilakukan yaitu uji validitas danuji reliabilitas. Instrumen angket yang diujikan berjumlah 30 pernyataan. Dan setelah melalui uji-uji tersebut, soal dinyatakan valid dan layak digunakan 
berjumlah 22 soal berdasarkan pada lampiran.

\section{a. Validitas Instrumen}

Uji validitas menggunakankorelasi Bivariate Pearson(korelasi produk momen Pearson). Analisis ini dengan cara mengkorelasikan masing-masing skor item dengan skor total. Pengujian menggunakan uji dua sisi dengan kriteria pengujian adalah sebagai berikut:

Jika $r$ hitung $\geq 0,30$ maka instrumen atau item-item pertanyaan berkorelasi signifikan terhadap skor total (dinyatakan valid).

- Jika $r$ hitung <0,30 maka instrumen atau item-item pertanyaan tidak berkorelasi signifikan terhadap skor total (dinyatakan tidak valid).

b. Reliabilitas Instrumen

Setelah uji validitas dilakukan agar angket yang digunakan benar-benar dapat dipercaya sebagai alat pengumpul data maka perlu di uji reliabilitas dengan teknik cronbach alpha.

Uji reliabilitas dalam hal ini mengacu pada nilai alpha yang dihasilkan dalam output SPSS. Dasar pengambilan keputusan dalam uji reliabilitas adalah jika nilai Alpha lebih besar dari $r$ kritis product moment maka item-item angket yang digunakan dinyatakan reliabel atau konsisten, sebaliknya jika nilai Alpha lebih kecil dari $r$ kritis product moment maka item-item angket yang digunakan dinyatakan tidak reliabel atau tidak konsisten.

Dari hasil perhitungan yang telah dilakukan, diperolehnilai reliabilitas itemitem angket $=0,853$, sedangkan nilai $r$ kritis product moment $=0,6$. Karena nilai alpha $>r$ kritis product moment, maka item-item angket kemampuan berkomunikasi siswa dapat dikatakan reliabel atau terpercaya sebagai alat pengumpul data dalam penelitian

\section{Observasi}

Secara umum pengertian observasi adalah cara menghimpun bahan-bahan keterangan (data) yang dilakukan dengan mengadakan pengamatan dan pencatatan secara sistematis terhadap fenomenafenomena yang sedang dijadikan sasaran pengamatan.Observasi ini dilakukan untuk mengamati pelaksanaan teknik permainan kelompok dalam pembelajaran bahasa Indonesia terhadap kemampuan berkomunikasi siswa.

\section{Dokumentasi}

Dokumentasi merupakan kegiatan pengambilan gambar atau foto-foto selama kegiatan penelitian berlangsung terutama pada saat pelaksanaan teknik permainan kelompok. Berguna juga untuk lebih menyakinkan terlaksananya penelitian sesuai dengan prosedur yang telah direncanakan

\section{Analisis deskriptif}

Analisis ini dimaksudkan untuk mendeskripsikan siswa yang diperoleh peserta didik setelah pelaksanaan teknik permainan kelompok dan yang diajar secara konvensional. Hal ini dimaksudkan untuk mengetahui jumlah sampel, skor tertinggi (maksimum), skor terendah (minimum), skor rata-rata, standar deviasi, variansi dan koefisien variasi dari kedua kelompok yang dihitung dengan menggunakan program aplikasi SPSS 20. Skor rata-rata diperoleh dari persamaan:

$$
\bar{x}=\frac{\sum f_{i} x_{i}}{\sum f_{i}}
$$

(Sudjana, 2005:70)

Dimana untuk data yang disusun dalam daftar distribusi frekuensi:

$x$ : Nilai rata-rata

$x_{i}$ : tanda kelas interval

$f_{i}$ : Frekuensi yang sesuai dengan tanda kelas $x_{i:}$

Standar deviasi diperoleh dari persamaan:

dengan :

$$
S=\sqrt{\frac{n \sum f_{i} x_{i}^{2}-\left(\sum f_{i} x_{i}\right)^{2}}{n(n-1)}}
$$


$x_{i}$ : tanda kelas interval

$f_{i}$ : Frekuensi yang sesuai dengan

$x_{i}$ : tanda kelas

$\mathrm{n}$ : Jumlah sampel $\left(\mathrm{n}=\Sigma f_{i}\right)$

koefisien variasi diperoleh dari persamaan:

Dengan:

$$
K V=\frac{S}{\bar{x}} x 100 \%
$$

$$
\begin{aligned}
& S=\text { standar deviasi } \\
& \bar{x}=\text { rata-rata skor }
\end{aligned}
$$

\section{Analisis inferensial}

Uji nomalitas dimaksudkan untuk mengetahui apakah data yang diperoleh berdistribusi normal atau tidak. Uji normalitas data dilakukan dengan menggunakan bantuan program aplikasi SPSS 20 menggunakan uji kolmogrovsmirnov dengan taraf signifikansi $\alpha=5 \%=$ 0,05 .

Uji normalitas menggunakan uji chikuadrat dengan persamaan sebagai berikut:

Keterangan:

$$
\chi^{2}=\sum_{i=1}^{k} \frac{\left(O_{i}-E_{i}\right)^{2}}{E_{i}}
$$

$x^{2}=$ Nilai chi - kuadrat

$\mathrm{k}$ = Banyaknya kelas interval

$\mathrm{O}_{\mathrm{i}}=$ Frekuensi pengamatan

$E_{i}=$ Frekuensi yang diharapkan

Apabila sig $>\alpha=0,05$ maka dapat diasumsikan bahwa data berdistribusi normal, sebaliknya apabila sig $<\alpha=0,05$ maka diasumsikan bahwa data tidak berdistribusi normal.

Di bawah ini disajikan hasilperhitungan uji normalitas keadaan awal kelas eksperimen dankelas kontrol:

Tabel 3.3 Hasil Perhitungan Uji Normalitas keadaan awal

\begin{tabular}{cccc}
\hline Kelas & Sig & $\begin{array}{c}\boldsymbol{\alpha}=\mathbf{5} \\
\mathbf{\%}\end{array}$ & Keterangan \\
\hline Eksperimen & 0,166 & 0,05 & Normal \\
\hline Kontrol & 0,200 & 0,05 & Normal \\
\hline
\end{tabular}

HASIL DAN PEMBAHASAN
Sebelum pelaksanaan teknik
permainan kelompok pada kelas eksperimen, telah dilakukan pengumpulan data pembelajaran berupa pree test yang dilaksanakan pada hari Sabtu tanggal 27 Agustus 2019 pada kelas eksperimen yang beerjumlah 10 siswa dan kelas kontrol yang berjumlah 10 siswa. Hasil pree test kelas kontrol dan kelas eksperimen dapat dilihat pada tabel 4.1 berikut:

Tabel 4.1 Gambaran kemampuan berkomunikasi siswa sebelum pelaksanaan teknik permainan kelompok

\begin{tabular}{clcccc}
\hline \multirow{2}{*}{$\begin{array}{c}\text { Rentang } \\
\text { Skor }\end{array}$} & Kategori & \multicolumn{2}{c}{ Kelas Eksperimen } & \multicolumn{2}{c}{ Kelas Kontrol } \\
\cline { 3 - 6 } & Frekuensi & $\begin{array}{c}\text { Persentas } \\
\text { e (\%) }\end{array}$ & Frekuensi & $\begin{array}{c}\text { Persentas } \\
\text { e (\%) }\end{array}$ \\
\hline $94-110$ & Sangat Tinggi & 0 & 0 & 0 & 0 \\
$76-93$ & Tinggi & 0 & 0 & 0 & 0 \\
$58-75$ & Cukup & 8 & 80 & 8 & 80 \\
$40-57$ & Rendah & 2 & 20 & 2 & 20 \\
$22-39$ & Sangat & 0 & 0 & 0 & 0 \\
\hline Jumlah & Rendah & & & & 10 \\
\hline
\end{tabular}

Berdasarkan tabel4.1 di atas menunjukkan bahwa kemampuan berkomunikasi dalam pembelajaran bahasa Indonesia, siswa kelas eksperimen dan kelas kontrol sebelum diberikan perlakuan memiliki kemampuan yang sama dilihat dari penyebaran dan frekuensinya.

Kemampuan berkomunikasi dalam permainan kelompok siswa sebelum diberikan perlakuan pada kelas V SDN 110 Lagoari yaitu hasil pemberian pree test diperoleh rata-rata pada kelas eksperimen yaitu 63,40, sedangkan nilai rata-rata hasil pree test pada kelas kontrol yaitu 63,60. Dari nilai rata-rata kedua kelas tersebut masih berada pada kategori cukup. Kelas eksperimen dan kelas kontrol mempunyai frekuensi yang sama yaitu 8 siswa pada kategori cukup dan 2 siswa pada kategori rendah hal ini menunjukkan bahwa kelas eksperimen dan kelas kontrol sebelum diberikan perlakuan memiliki kemampuan awal yang sama.

a. Gambaran kemampuan berkomunikasi dalam pembelajaran bahasa Indonesia, 
siswa setelah pelaksanaan teknik permainan kelompok

Setelah pelaksanaan teknik permainan kelompok pada kelas eksperimen, maka diberikan post test yang dilaksanakan pada Rabu tanggal 5 September 2019 pada kelas eksperimen yang berjumlah 10 siswa dan kelas kontrol yang berjumlah 10 siswa. Diperoleh hasil post test adanya perbedaan kemampuan berkomunikasi dalam pembelajaran bahasa Indonesia, siswa yang signifikan dari kedua kelas tersebut. Ini terbukti pada hasil post test yang disajikan pada tabel berikut

Tabel 4.2 Gambaran kemampuan berkomunikasi dalam pembelajaran bahasa Indonesia, siswa setelah pelaksanaan teknik permainan kelompok

Berdasarkan tabel 4.2 di atas menunjukkan bahwa kemampuan berkomunikasi dalam pembelajaran bahasa Indonesia, siswa kelas eksperimen dan kelas kontrol setelah diberikan perlakuan memiliki kemampuan yang memiliki perbedaan yang signifikan dilihat dari penyebaran dan frekuensinya.

Kemampuan berkomunikasi dalam pembelajaran bahasa Indonesia, siswa setelah diberikan perlakuan pada kelas $\mathrm{V}$ SDN 110 Lagoari yaitu hasil pemberian post test diperoleh rata-rata pada kelas eksperimen yaitu 80,10 , sedangkan nilai rata-rata hasil pree test pada kelas kontrol yaitu 66,60. Dari nilai rata-rata kedua kelas tersebut terdapat perbedaan yang signifikan, kelas kontrol masih berada pada kategori cukup sedangkan kelas eksperimen berada pada kategori tinggi. Kelas eksperimen mempunyai frekuensi yaitu 7 siswa pada kategori tinggi dan 3 siswa pada kategori cukup, sedangkan pada kelas kontrol yaitu 1 siswa pada kategori tinggi dan 9 siswa pada kategori cukup.

Bagian ini membahas tentang hasil analisis data penelitian tentang pembelajaran bahasa indonesia dengan teknik permainan kelompok terhadap siswa kelas $\mathrm{V}$ di SDN 110 Lagoari Berdasarkan hasil analisis data melalui angket siswa, telah ditemukan bahwa tingkat kemampuan berkomunikasi siswa pada kelompok kontrol peningkatan yang tidak terlalu tinggi, hal ini dibuktikan oleh hasil rata-rata perbandingan antara nilai pree test dengan kategori cukup, sedangkan hasil rata-rata post test berada pada kategori cukup.

Sedangkan tingkat kemampuan berkomunikasi dalam pembelajaran bahasa Indonesia, siswa kelas eksperimen mengalami peningkatan. Tingkat kemampuan berkomunikasi siswa kelas $\mathrm{V}$ SDN 110 Lagoari sebelum diberikan teknik permainan kelompok berada dalam

\begin{tabular}{|c|c|c|c|c|c|}
\hline \multirow{2}{*}{$\begin{array}{l}\text { Rentang } \\
\text { Skor }\end{array}$} & \multirow[b]{2}{*}{ Kategori } & \multicolumn{2}{|c|}{$\begin{array}{c}\text { Kelas } \\
\text { Eksperimen }\end{array}$} & \multicolumn{2}{|c|}{ Kelas Kontrol } \\
\hline & & $\begin{array}{l}\text { Freku } \\
\text { ensi }\end{array}$ & $\begin{array}{c}\text { Persen } \\
\text { tase } \\
(\%)\end{array}$ & $\begin{array}{c}\text { Frekue } \\
\text { nsi }\end{array}$ & $\begin{array}{c}\text { Persen } \\
\text { tase } \\
(\%)\end{array}$ \\
\hline & Sangat & 0 & 0 & 0 & 0 \\
\hline $94-110$ & Tinggi & 7 & 70 & 1 & 10 \\
\hline $76-93$ & Tinggi & 3 & 30 & 9 & 90 \\
\hline $58-75$ & Cukup & 0 & 0 & 0 & 0 \\
\hline $40-57$ & Rendah & 0 & 0 & 0 & 0 \\
\hline \multirow[t]{2}{*}{$22-39$} & Sangat & & & & \\
\hline & Rendah & & & & \\
\hline Jumlah & & 10 & 100 & 10 & 100 \\
\hline
\end{tabular}

kategori cukup, terlihat dari siswa yang pada saat di sekolah baik di dalam kelas, dan di luar kelas serta saat kegiatan pembelajaran siswa masih memiliki sikap keterbukaan, empati, mendorong/dukungan, perasaan positif dan kesamaan yang masih cukup rendah. Menurut De Vitto dalam Widjaja (2000: 127) komunikasi agar menjadi efektif yaitu dengan: keterbukaan, empati, dorongan, perasaan positif dan kesamaan.Tingkat kemampuan berkomunikasi siswa kelas $\mathrm{V}$ SDN 110 Lagoari setelah diberikan teknik permainan kelompok berada dalam kategori tinggi yang terlihat dari siswa pada saat pembelajaran siswa sudah dapat bersikap dengan terbuka, memiliki empati 
pada teman, memberikan dorongan/dukungan pada teman, siswa memiliki perasaan positif pada teman dan siswa dapat menerapkan sikap kesamaan pada teman..

Perbedaan signifikan kemampuan berkomunikasi antara kelas eksperimen dan kelas kontrol dapat disebabkan oleh perbedaan sintaks atau langkah-langkah pada proses pembelajaran. Pembelajaran dengan teknik permainan kelompok memanfaatkan ruang kelas sebagai sarana permainan sehingga tanpa anak sadari, anak bermain dan menikmati itu dan disitu ia belajar banyak hal yang bisa ia tanamkan dalam hidupnya salah satunya adalah belajar meningkatkan kempuan komunikasi, tanpa anak sadari saat bermain mereka akan belajar berkomunikasi dengan temannya dengan suasana yang nyaman dan santai tersebut anak tidak merasa tegang dan tertekan sehingga lebih mudah dan tidak canggung. sesuai dengan apa yang disebutkan oleh Romlah (2001: 118) permainan merupakan cara belajar yang menyenangkan karena dengan bermain anak-anak belajar sesuatu tanpa mempelajarinya

Dari permainan yang diadakan tersebut akan terlihat bagaiman interaksi dari siswa, permainan yang digunakanpun permainan yang sesuai dengan tujuan yang ada yaitu permainan yang dapat meningkatkan kemampuan bekomunikasi siswa. Pada setiap pertemuan permainan disesuaikan dengan materi yang diberikan pada sesi tersebut sehingga untuk mengamati indakor yang ada muncul atau tidak selain itu juga untuk merangsang siswa sebelum pembahasan materi yang akan diberikan pada pertemuan tersebut.

Kegiatan belajar dan aktifitas siswa yang mengikuti pembelajaran teknik permainan kelompok terlihat lebih aktif dan antusias belajar. Hal tersebut tidak terlepas dari kegiatan pembelajaran yang memberikan kesempatan kepada siswa untuk berinteraksi dengan temannya atau kelompok lain. Hal tersebut berbeda dengan pembelajaran tanpa perlakuan teknik permainan kelompok atau biasa juga diistilahkan pembelajaran tradisional. Siswa lebih banyak belajar secara prosedural. Guru lebih banyak mendominasi kegiatan pembelajaran sehingga terkesan guru hanya mentransfer ilmunya kepada siswa. Siswa hanya berperan sebagai pendengar pasif dan mengerjakan apa yang disuruh guru serta melakukannya sesuai dengan yang dicontohkan. Interaksi antar siswa jarang terjadi, interaksi didominasi dari guru ke siswa saja. Pembelajaran seperti ini jelas membuat siswa tidak terlatih untuk berkomunikasi dan hanya menunggu perintah dari guru saja. Hal ini menyebabkan siswa merasa tertekan, takut, pembelajaran tidak menarik, cepat bosan, sehingga efeknya adalah rendahnya kemampuan berkomunikasi siswa.

Hasil analisis data penelitian ini memberikan gambaran adanya pengaruh pelaksanaan teknik permainan kelompok terhadap kemampuan berkomunikasi siswa di sekolah dasar. Meskipun demikian dalam melaksanakan penelitian ini beberapa temuan yang menjadi kendala pada saat pelaksanaan pembelajaran terutama pada kelas eksperimen. Pada pertemuan pertama pelaksanaan pembelajaran masih kaku terutama pada kegiatan siswa. Siswa masih malu-malu dalam bekerjasama dengan teman kelompoknya terutama yang berbeda genre. Keterampilan komunikasi siswa masih kurang sehingga dalam melakukan permainan masih ragu dan kekurangan perbendaharaan kata untuk menanggapi atas perbedaan pendapat dengan kelompok. Begitu pula dengan interaksi kepada guru dan siswa. Pada pertemuan berikutnya berjalan lebih lancar sampai pada pertemuan keempat. Padatnya kegiatan akademik siswa juga terkadang 
berjalan tidak sesuai dengan rencana. Akan tetapi kendala tersebut tidak menghalangi keterlaksanaan penelitian dengan baik.

Hasil penelitian ini menunjukkan bahwa pelaksanaan teknik permainan kelompok berpengaruh positif terhadap kemampuan berkomunikasi siswa di sekolah dasar. Begitupula hasil pada kelompok kontrol terdapat peningkatan rata-rata kemampuan berkomunikasi siswa, namun pada kategori yang tetap sama yaitu kategori cukup. Hal ini berarti meningkatnya kemampuan berkomunikasi siswa tidak hanya dipengaruhi oleh pendekatan, model, dan metode pembelajaran saja. Faktor lain yang juga sangat berpengaruh adalah guru. Guru sangat berperan dalam keberhasilan pembelajaran. Guru tidak hanya motivator tapi juga sebagai inspirator bagi siswa untuk meningkatkan kemampuan berkomunikasi siswa di sekolah dasar.

Penggunaan teknik permainan kelompok perlu disosialisasikan dan diterapkan pada setiap jenjang maupun sub pokok bahasan. Pembelajaran dengan teknik permainan kelompok dapat dijadikan sebagai salah satu alternatif solusi dalam rangka meningkatkan kemampuan berkomunikasi siswa di sekolah dasar.

\section{Simpulan}

Berdasarkan hasil penelitian dalam meningkatkan kemampuan berkomunikasi dalam pembelajaran bahasa Indonesia, siswa dengan judul "Pembelajaran Bahasa Indonesia Dengan Teknik Permainan Kelompok Siswa Kelas V di SDN 110 Lagoari Kabupaten Wajo " dapat disimpulkan bahwa:

1. Pelaksanaan pembelajaran teknik permainan kelompok pada pembelajaran kelas eksperimen terlaksana dengan baik sesuai langkahlangkah pembelajaran yang disesuaikan dengan masing-masing permainan yang digunakan tiap pertemuan yang mengacu pada karakteristik teknik permainan kelompok yaitu pra bermain, saat bermain, dan pasca bermain.

2. Tingkat kemampuan berkomunikasi dalam pembelajaran bahasa Indonesia, siswa kelas V SDN 110 Lagoari sebelum diberikan teknik permainan kelompok berada dalam katagori cukup, setelah pelaksanaan teknik permainan kelompok berada dalam kategori tinggi.

3. Tingkat kemampuan berkomunikasi dalam pembelajaran bahasa Indonesia, siswa kelas V SDN 110 Lagoari dapat ditingkatkan. Berdasarkan perhitungan uji Independent Sample $t$ Test, pelaksanaan teknik permainan kelompok berpengaruh terhadap siswa.

\section{DAFTAR PUSTAKA}

[1] Depdiknas. 2003. Kamus Besar Bahasa Indonesia. Jakarta: Balai Pustaka

[2] Fathurrohman Pupuh \& M. Sobry Sutikno. 2007. Strategi Belajar Mengajar melalui Penanaman Konsep Umum \& Konsep Islami. Bandung : PT Refika Aditama.

[3] Freeman, Joan dan Utami Munandar. 2001. Cerdas Dan Cemerlang. Jakarta : Gramedia Pustaka.

[4] Furqon. 2005. Konsep dan Aplikasi Bimbingan Dan Konseling Di Sekolah Dasar. Bandung : Pustaka Bani Quraisy.

[5] Haryanto. 2010. Metode Permainan dalam Pembelajaran, (Online). (http://belajarpsikologi.com/metod e-permainan-dalam-pembelajaran/, Diakses 22 Oktober 2015)

[6] Huda Miftahul. 2015. Cooperative Learning Metode, Teknik, Struktur dan Model Penerapan. Yogyakarta : Pustaka Pelajar. 
[7] Hurlock, Elizabeth B. 2010. Psikologi Perkembangan Anak Jilid I. Jakarta : Erlangga.

[8] Prayitno. 1995. Layanan Bimbingan dan Konseling Kelompok Dasar dan Profil. Jakarta : Ghalia Indonesia

[9] Program Pascasarjana Universitas Negeri Makassar. 2010. Pedoman Penulisan Tesis dan Desertasi. Makassar : Badan Penerbit UNM

[10] Puspawarna. 2010. Belajar kelompok, (Online). (http://puspawarnapuspawarna.blogspot.co.id /2010/05/belajar- kelompok.html, Diakses 21 Oktober 2015)

[11] Restyowati, Donik dan Najlatun Narqiyah. 2010. Jurnal : Penerapan Teknik Permainan Kerjasama Untuk meningkatkan Kemampuan Interaksi Sosial Pada Siswa.

[12] Romlah, Tatiek. 2001. Teori Dan Praktik Bimbingan Dan Konseling. Jakarta : Erlangga.

[13] Roni ir. 2012. Belajar Kelompok, (Online), (http://roniir.blogspot.co.id/2012/0 3/ belajar-kelompok.html, Diakses 21 Oktober 2015)

[14] Santrock, John W. 2002. Life Span Development Perkembangan Masa Hidup Jilid I. Jakarta : Erlangga.

[15] Sefrian. 2011. Strategi Pembelajaran Kelompok, (Online). (http://sefrian92.blogspot.co.id/20 11/02/strategi-pembelajarankelompok.html, Diakses 21 Oktober 2015)

[16] Sobry Sutikno, 2014. Metode \& Model-model Pembelajaran "Menjadikan Proses Pembelajaran Lebih Veriatif, Aktif, Inovatif, Efektif, dan Menyenangkan". Mataram : Holitica Lombok

[17] Subana, Cucu. 2000. Konsep Strategi Pembelajaran. Bandung: PT. Refika Aditama.

[18] Sugiyo. 2005. Komunkasi Antar Pribadi. Semarang : UNNES Press

[19] Sudjana. 2005. Metode Statistik. Bandung: Tarsito.

[20] Sukmadinata Nana Syaody. 2010. Metode Penelitian Pendidikan. Bandung : PT Remaja Rusda Karya

[21] Supratiknya. 1995. Komunikasi Antar Pribadi Tinjauan Psikologi. Yogyakarta : Kanisius

[22] Tarrigan Henri Guntur. 1981. Berbicara Sebagai Suatu Keterampilan Berbahasa. Bandung : CV. Angkasa.

[23] Wahyudin, 2008. Pembelajaran dan Model-model Pembelajaran (Pelengkap untuk Meningkatkan Kompetensi Pedagogis para Guru dan Calon Guru Profesional) Seri 3. Jakarta : CV. Ipa Abong

[24] Widjaja, H.A.W. 2000. IImu Komunikasi Pengantar Studi. Jakarta: Rineka Cipta

[25] Widoyoko, 2013. Evaluasi Program Pembelajaran. Yogyakarta: Pustaka Pelajar.

\section{PROFIL PENULIS}

$\begin{array}{lrr}\text { Surianto, S.Pd } & \text { merupakan } \\ \text { mahasiswa pascasarjana } & \text { magister } \\ \text { pendidikan dasar di } & \text { Universitas } \\ \text { Muhammadiyah Makassar. Penulis lahir di } \\ \text { Lagoari, 09 April } & \text { 1982. Pendidikan sarjana } \\ \text { S1 ditempuh } & \text { di } & \text { Universitas } \\ \text { Muhammadiyah } & \text { Makassar } & \text { jurusan } \\ \text { Pendidikan Guru } & \text { Sekolah } & \text { Dasar }\end{array}$

